\title{
Commentary: Disparities in use of durable mechanical circulatory support device: Does ethnicity tilt the balance?
}

\author{
Ademola Adeseye, MD, and Ravi K. Ghanta, MD
}

\footnotetext{
From the Division of Cardiothoracic Surgery, Michael E. DeBakey Department of Surgery, Baylor College of Medicine, Houston, Tex.

Disclosures: Authors have nothing to disclose with regard to commercial support.

Received for publication Oct 8, 2019; revisions received Oct 8, 2019; accepted for publication Oct 8, 2019; available ahead of print Oct 24, 2019.

Address for reprints: Ravi K. Ghanta, MD, Division of Cardiothoracic Surgery, Michael E. DeBakey Department of Surgery, Baylor College of Medicine, One Baylor Plaza, MC 390, Houston, TX 77030 (E-mail: Ravi. ghanta@bcm.edu).

J Thorac Cardiovasc Surg 2021;161:135-6

$0022-5223 / \$ 36.00$

Copyright (C) 2019 Published by Elsevier Inc. on behalf of The American Association for Thoracic Surgery

https://doi.org/10.1016/j.jtcvs.2019.10.047
}

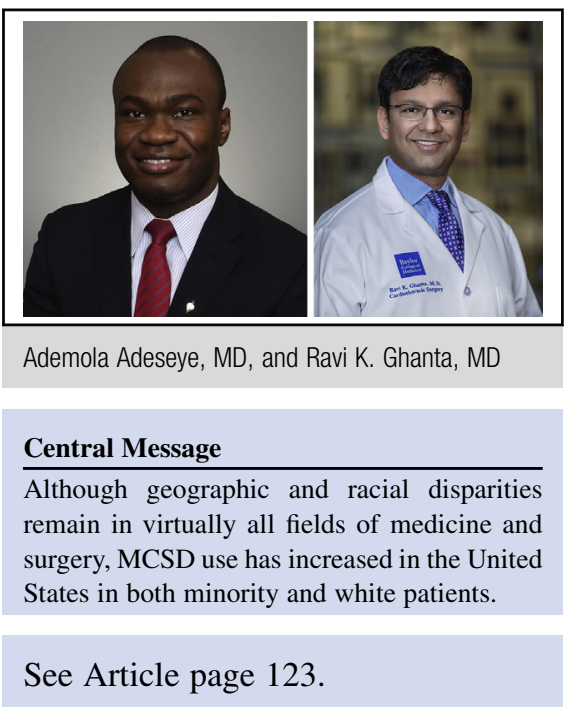

Another important finding from this study is the overall use of MCSD has increased throughout the United States. Across all 11 United Network for Organ Sharing regions, rate of annual MCSD implantation increased from 5.14 MCSD/million population to $13.97 \mathrm{MCSD} / \mathrm{million}$ population-a near tripling of MCSD use. Clearly this game-changing therapeutic strategy for the management of patients with advanced heart failure is being increasingly used. Although geographic and racial disparities remain in virtually all fields of medicine and surgery, MCSD use has increased in the United States in both minority and white patients. Further studies to investigate additional disparities in MCSD and heart transplantation access are warranted.

\section{References}

1. Rose EA, Gelijns AC, Moskowitz AJ, Heitjan DF, Stevenson LW, Dembitsky W, et al. Long-term use of a left ventricular assist device for end-stage heart failure. $N$ Engl J Med. 2001;345:1435-43.

2. Hannan EL, Kilburn H Jr, O’Donnell JF, Lukacik G, Shields EP. Interracial access to selected cardiac procedures for patients hospitalized with coronary artery disease in New York State. Med Care. 1991;29:430-41.

3. Konety SH, Vaughan Sarrazin MS, Rosenthal GE. Patient and hospital differences underlying racial variation in outcomes after coronary artery bypass graft surgery. Circulation. 2005;111:1210-6.

4. Clerkin KJ, Garan AR, Wayda B, Givens RC, Yuzefpolskaya M, Nakagawa S et al. Impact of socioeconomic status on patients supported with a left ventricular assist device: an analysis of the UNOS Database (United Network for Organ Sharing). Circ Heart Fail. 2016;9.

5. Krim SR, Vivo RP, Campbell P, Estep JD, Fonarow GC, Naftel DC, et al. Regiona differences in use and outcomes of left ventricular assist devices: insights from the Interagency Registry for Mechanically Assisted Circulatory Support Registry. J Heart Lung Transplant. 2015;34:912-20. 
6. Bourque JL, Liang Q, Pagani FD, Zhang M, Aaronson KD, Kormos RL, et al; Michigan Congestive Heart Failure Investigators (MiCHF). Durable mechanical circulatory support device use in the United States by geographic region and minority status. J Thorac Cardiovasc Surg. 2021;161:123-33.e13.
7. Benjamin EJ, Muntner P, Alonso A, Bittencourt MS, Callaway CW, Carson AP, et al. Heart disease and stroke statistics-2019 update: a report from the American Heart Association. Circulation. 2019;139: e56-528. 